This document contains new concepts or the author(s) interpretation of new calcuiations and/or measurements; accordingly, EG\&G Idaho, Inc. is required by the United Siates Government to include the following disclaimer:

\section{DISCLAIMER}

This repc.i was prepared as an account of work sponsored by an agency of the United States Government. Neither the United States Government nor any agency thereof, nor any of their employee's, makes any warranty, express or implied, or assumes any legal liability or responsibility for the accuracy, completeness, or usefulness of any information, apparatus, product or process disclosed, or represents that its use would not infringe privately owned rights. References herein to any specific commercial product, process, or service by tráde name, trademark. manulacturer, or otherwise, does not necessarily constitute or imply its endorsement, recommendation, or favoring by the United States Government or any agency thereof. The views and opinions of authors expressed herein do not necessarily state or reflect those of the United States Government or any agency thereof. 
EGG-WTD--9594-Vol . 1

DE92 003326

\title{
PRELIMINARY SYSTEMS DESIGN STUDY ASSESSMENT REPORT
}

\section{VOLUME I EXECUTIVE SUMMARY}

\author{
J. L. Mayberry \\ W. J. Quapp \\ F. Feizollahi \\ J. C. Del Signore
}

Published July 1991

Idaho National Engineering Laboratory EG\&G Idaho, Inc. Idaho Falls, Idaho 83415

Prepared for the

U.S. Department of Energy Idaho Operations office

Under DOE Contract No. DE-AC07-76ID01570

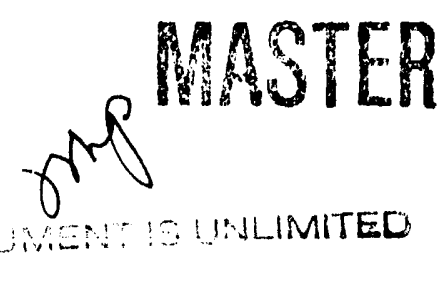


$\mathbf{I}-\mathbf{i} \mathbf{i}$ 
PRELIMINARY SYSTEMS DESIGN STUDY ASSESSMENT REPORT

EGG-WTD-9594

Prepared by:
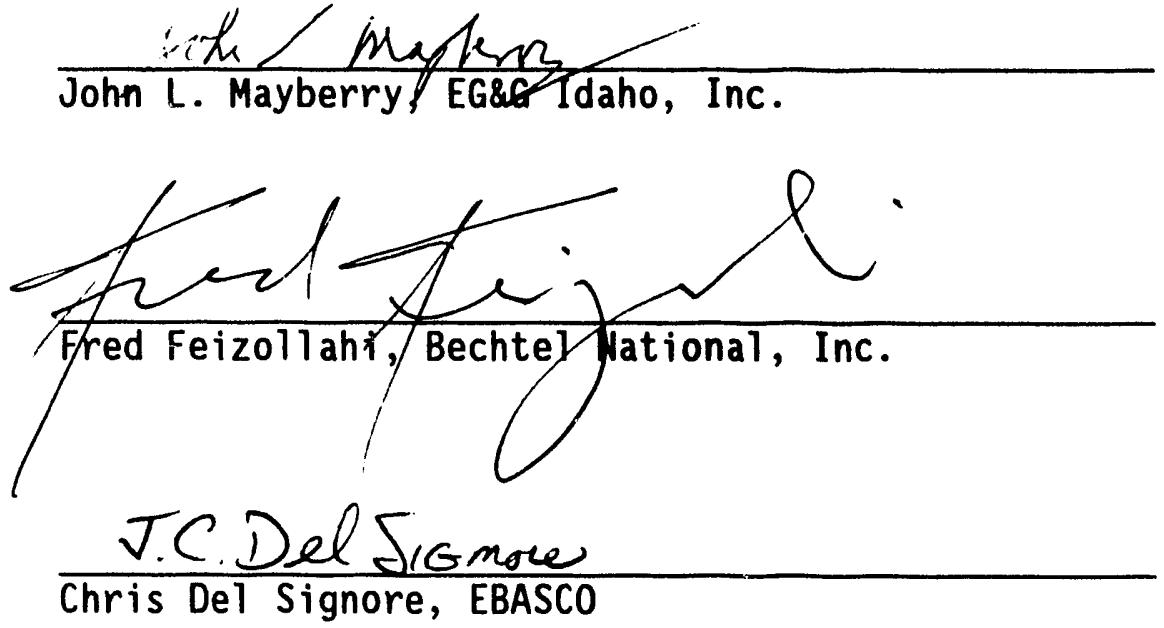

$\frac{7-9-9}{\text { Date }}$

$\frac{7-9-91}{\text { Date }}$

$\frac{7-09-91}{\text { Date }}$

Reviewed and Approved by:
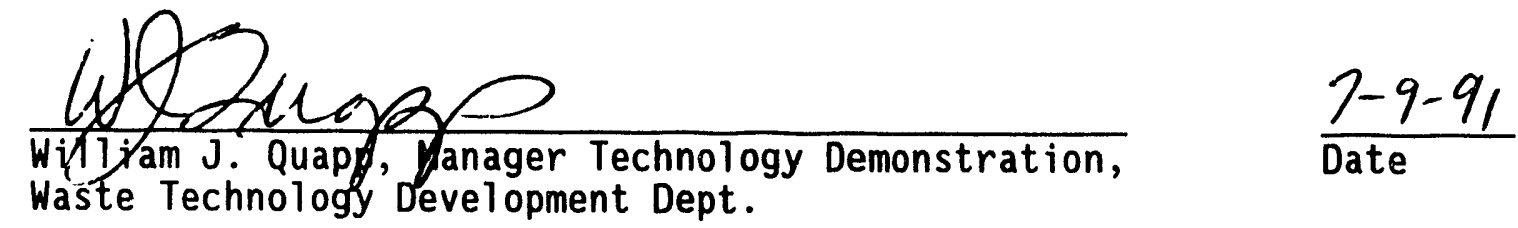


\section{ABSTRACT}

The System Design Study (SDS), part of the Waste Technology Development Department at Idaho National Engineering Laboratory (INEL), examined techniques available for the remediation of hazardous and transuranic (TRU) waste stored at the Radioactive Waste Management Complex's (RWMC's) Subsurface Disposal Area (SDA) at INEL. Using specific technologies, system concepts for treating the buried waste and the surrounding contaminated soil were evaluated. Evaluation included implementability, effectiveness, and cost. SDS resulted in the development of technology requirements including demonstration, testing and evaluation activities needed for implementing each concept.

The SDS results are published in eight volumes. Volume I contains an executive summary. The SDS summary and analysis of results are presented in Volume II. Volumes III through VII contain detailed descriptions of twelve system and four subsystem concepts. Volume VIII contains the appendices. 


\section{ACKNOWLEDGMENTS}

The authors would like to acknowledge the efforts of those that contributed to this report.

EG\&G Idaho, Inc., Bechtel National, Inc., Ebasco Environmental, and IT Corp. for providing the assessments and functional and operational requirements for the 12 system and 4 subsystem concepts. Specifically, C. Klassy, K. Sherick and D. Haifner of EG\&G Idaho, Inc., R. Schlueter, M. Pong, D. Harris, M. Beathal'd and P. Yen of Bechtel National, Inc., D. Prinzing, J. Bjorkstam, R. Vankateswar and S. Peck of Ebasco Environmental, J. Plum, J. Valdez, D. Vetter, M. Chavez, S. Djordevic, M. Swientoniewski of IT Corp., and H. Kresny of Solmont Corporation.

Karen Grant and Janalee Nelson of EG\&G Idaho, and Debra Iniquez of Bechtel National, Inc., for the extra effort required in editing this report. 


\section{CONTENTS}

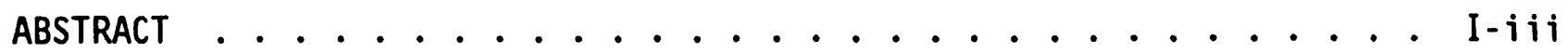

ACKNOWLEDGMENTS ....................... I- iv

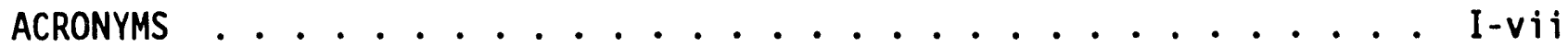

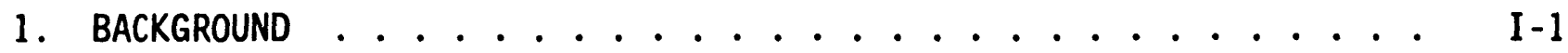

2. SYSTEM DESIGN STUDY SCOPE ................ I-2

3. MISSION NEED, OBJECTIVES AND CONSTRAINTS .......... I-3

4. BURIED WASTE PROPERTY ASSUMPTIONS ............. I-5

5. FINAL WASTE FORM ASSUMPTIONS .............. I-6

6. DEVELOPMENT OF SYSTEM CONCEPTS .............. I-7

7. CONCEPTS PRODUCING WASTE FORM $1 \ldots \ldots \ldots$ I-8

8. CONCEPTS PRODUCING WASTE FORM $2 \ldots \ldots \ldots$ I-10

9. CONCEPTS PRODUCING WASTE FORM $3 \ldots \ldots \ldots$ I-12

10. CONCEPTS PRODUCING WASTE FORM $4 \ldots \ldots \ldots$ I-15

11. SUBSYSTEM CONCEPTS .................. I-16

12. CONCEPT IMPLEMENTATION RISK ASSESSMENT SUMMARY . . . . . . I-18

13. SUMMARY OF ROUGH ORDER OF MAGNITUDE (ROM) COST ESTIMATES . . . . I-20

14. RDDT\&E SUMMARY SCHEDULE ................. I-22

15. RECOMMENDATIONS ........................... I-24

5.1 Technical Requirements Development Strategy ........ I-24

5.2 System Concepts Ranking Strategy ... . . . . . . . . I-24

15.3 Acceptable Concepts ............... I-26

15.4 Recommendations for Future Activities .......... I-29 


\section{FIGURES}

I-1. Systems cost estimates summary .............. I-21

I-2. Summary of DT\&E schedules for systems and subsystems ..... I-23

I-3. System and subsystem concepts considered In the SDS and major program decision needs ................ I-25

\section{TABLES}

I-1. Program implementation risk summary ........... I-19

I-2. System concepts ranking ............... I-27

I-3. DT\&E summary .................. I-30 


\section{ACRONYMS}

ARAR Applicable Relevant and Appropriate Requirements

CAA Clean Air Act

CEQ Council of Environmental Quality

CERCLA Comprehensive Envirormental Response, Compensation, and Liability ACt

CM construction management

CWA Clean Water Act

DOE Department of Energy

DOE-ID Department of Energy Idaho Operations Office

DT\&E demonstration, testing, and evaluation

EPA Environmental Protection Agency

ER Environmental Restoration

F\&OR Functional and Operational Requirement

FFBD functional flow block diagram

FOM Figure of Merit

FS feasibility study

GPR ground penetrating radar

HEPA high-efficiency particulate air (filter)

IAG Interagency Agreement

INEL Idaho National Engineering Laboratory

I/0 input/output

ISV in situ vitrification

LDR land disposal restriction

LLW low-level waste

MSA Major System Acquisition

MSO Molten Salt Oxidation

NEPA National Environmental Policy Act of 1969 


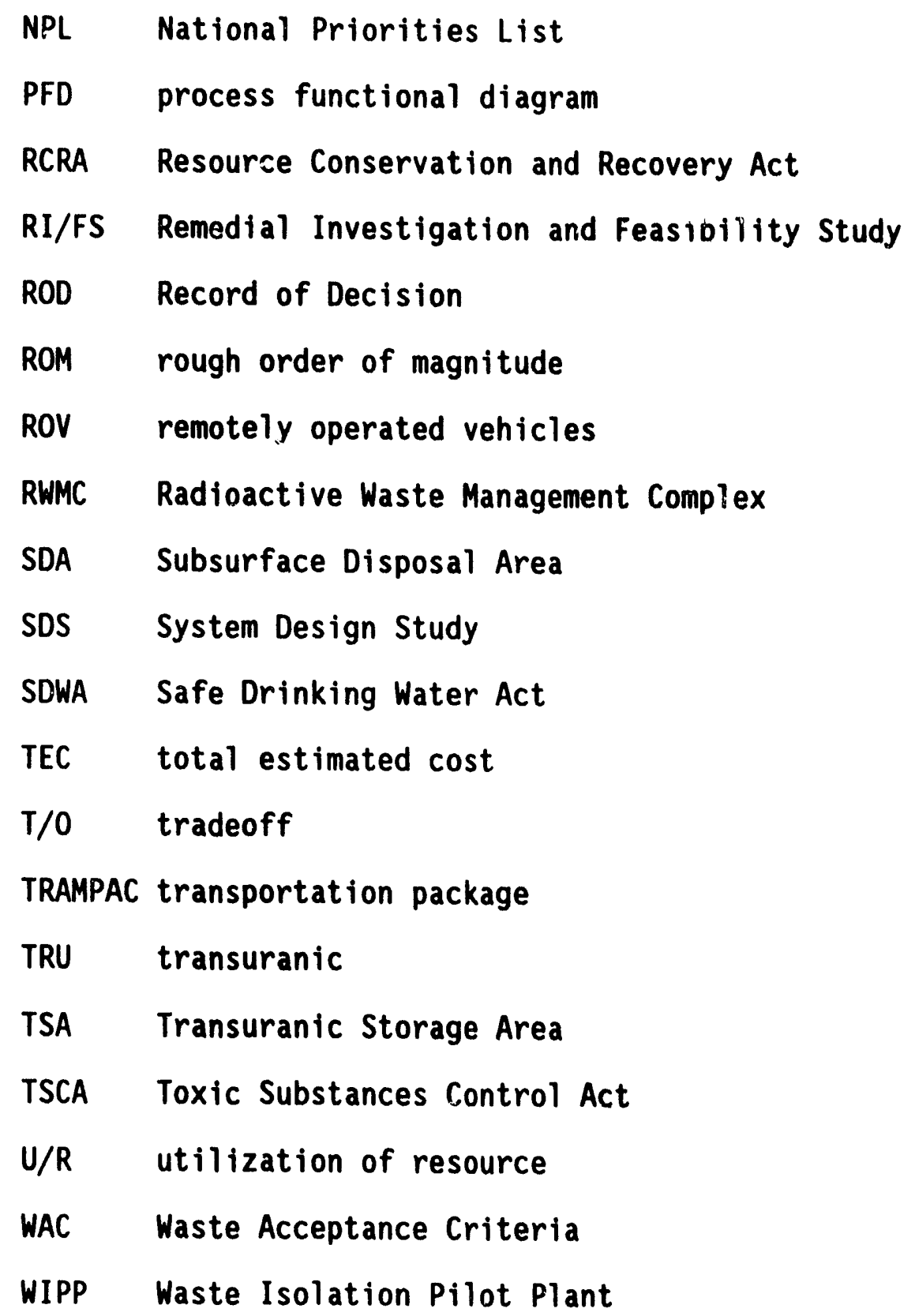




\section{VOLUME I \\ EXECUTIVE SUMMARY}

\section{BACKGROUND}

On November 15, 1989, the Idaho National Engineering Laboratory (INEL) was placed on the Environmental Protection Agency's (EPA's) list of priority sites for cleanup, known as the National Priorities List (NPL). This mandates remediation of plutonium-(Pu) contaminated waste buried at the Subsurface Disposal Area (SDA) under the Comprehensive Environmental Response, Compensation and Liability Act (CERCLA). Accordingly, a remedial action option for the buried waste will be decided via the CERCLA decision process. The selected option could be either no action, an in sicu treatment and disposal (such as in situ vitrification, containment, etc.), or ex situ treatment and disposal (such as retrieval followed by soil washing, melting, incineration, etc.).

The Department of Energy Idaho Operations Office (DOE-ID) has established a Buried Waste Program to conduct the SDA site assessment and remedial action in compliance with CERCLA. Pu-contaminated waste buried at the SDA includes both disposed liquid and solids of varying transuranic (TRU) concentration and special-case wastes placed in drums and cardboard boxes in random and stacked configurations. Recent studies have shown a migration of contaminants from the SDA towards the Snake River Plain Aquifer. Although a number of options for the remediation of the TRU buried waste at the SDA have been studied and evaluated in the past, no specific treatment strategy has been established to date. 


\section{SYSTEM DESIGN STUDY SCOPE}

Remediation of SDA will require a complex set of technologies for safe treatment and disposal of the waste. A key question for achieving the Buried Waste Program objectives is to identify what are the practical and cost effective technologies that could be used to satisfy the objectives of this Program. To provide an answer to this question, a System Design Study (SDS), hased on system engineering principles advocated by DOE Order 4700.1, was commissioned. The systems engineering process is a sequence of activities and decisions that transform an identified mission need into a description of system performance parameters and a preferred systam configuration.

The SDS examined the existing as well as emerging technologies for cost-effective remediation of the buried waste. While examining the technology options, the SDS focused on the technology requirements aspect of the systems engineering process. The intent was to identify a set of cost-effective, practical, and acceptable treatment strategies, develop system concepts encompassing these strategies, and identify technologies within these concepts which wi,l require demonstration, testing and evaluation (DT\&E). The results are to provide input to DOE's decision making process and allow definition of more detailed requirements for the system. The scope of the SDS was not to select an optimum waste form or an optimum strategy at this time. Also, SDS did not address facilities for disposal of waste from ex situ treatment concepts. 


\section{MISSION NEED, OBJECTIVES AND CONSTRAINTS}

The Buried Waste Program mission is to ensure that (a) the environmental impacts associated with past and present activities at the SDA site are thoroughly investigated and (b) appropriate remedial action be taken as necessary to protect the public health and welfare and the environment. Program objectives are as follows:

- Performance Objectives: Baseline cleanup standards for buried waste sites at the Radioactive Waste Management Complex (RWMC) cannot be established until a Record of Decision (ROD) pursuant to the CERCLA process is reached for the Remedial Action. These standards will be derived through (a) the Applicable or Relevant and Appropriate Requirements (ARARs) process under CERCLA, (b) standaras set by risk assessments, and (c) the state (and local) statutes requirements.

- Health and Safety: Key health and safety objectives are to (a) identify the hazards of the remedial action operation and (b) provide measures to el iminate, control, or mitigate identified hazards.

- Institutional Objectives: Key instituional objectives are to involve the state agencies and the public in the process of selecting a remedial action for the buried waste and ensure compliance with the National Environmental Policy Act (NEPA) and CERCLA public participation requirements.

- Schedule Objectives: The objective schedule is to reach a Record of Decision (ROD) under CERCLA as early as possible but no later than FY-2001. The schedule objective is to complete the Buried Waste Program as early as possible but no later than FY-2019. 
- Cost Objective: At this time, the cost objective for the Buried Waste Program is cost-effectiveness. A baseline budget has not been established yet. 


\section{BURIED WASTE PROPERTY ASSUMPTIONS}

Waste property data from the historical, as well as data from the past, site characterization efforts were compiled for use by the SDS. Since the compiled data was not sufficient to carryout the study, several assumptions and estimations were made. Accordingly, the total volume of the buried waste and the contaminated peripheral soil were estimated to be 2.3 and 9.7 million cubic feet, respectively. Forty percent of the buried waste was assumed to be low-level waste (LLW) containing less than 100-nanocuries/g of TRU waste. Ninety percent of the soil was assumed to be LLW or clean. Waste containing materials that can jeopardize the safety of retrieval and processing operations was assumed either to exist in small quantities that can be safely handled, or to be segregated out for handling and processing as special material. The system concepts did not include capability to process special material. It was assumed that treatment capability for special material will be provided on a case-by-case basis. 


\section{FINAL WASTE FORM ASSUMPTIONS}

Since specific requirements for waste form cannot be defined at this stage of the Buried Waste Program, the SDS examined all of the possible disposal options. Based on this examination, four generic waste forms were identified: waste form 1 is based on applying in situ (process in-place, leave in-place) treatment concepts; waste form 2 is based on a leach resistant, high integrity structure (i.e., glass or rock); waste form 3 is based on satisfying 1 and disposal restriction (LDR) requirements and minimizing hydrogen generation; and, waste form 4 is based on Waste Isolation Pilot Plant (WIPP) and TRAMPAC (transportation package) acceptance criteria. System concepts examined by the SDS are based on producing an output that meets one or more of the established waste forms. 


\section{DEVELOPMENT OF SYSTEM CONCEPTS}

Using functional allocation and functional analysis techniques advocated by systems engineering process, an initial set of 73 optional system concepts were developed. The similar system concepts were then combined into 27-system with 4-subsystem concepts. From the 27-system concepts, 12-concepts were selected for further evaluation. A description of the 12 system and 4-subsystem concepts evaluated in the SDS is presented below. 


\section{CONCEPTS PRODUCING WASTE FORM 1}

Two in situ concepts were selected for detailed development and assessment: Barrier (1-BE-1), and In Situ Vitrification (ISV) (1-EB-2). The Barrier concept isolates the waste in situ by means of manmade barriers over, under, and around the waste pits and trenches. The ISV process is accomplished through the use of movable electrodes to sustain an electrical current capable of heating the waste material to $3600^{\circ} \mathrm{F}$ and producing a molten material that will pyrolyze the combustibles and organics and dissolve the inorganics. Upon cooling, the resultant vitreous and crystalline waste form resembles natural rocks.

In the Barrier concept, low leachability is accomplished by designing the barrier structures so they have a very low permeability. The Barrier System will require a leachate collection and monitoring unit installed inside the barrier and groundwater monitoring wells installed in the outside perimeter.

The ISV process slows down contamination migration by confining the contaminants in a high-quality glass waste form which has low leachability. The ISV process will require groundwater monitoring wells installed in the outside perimeter. Once the Barrier or ISV concepts are implemented, there are no other activities required, except monitoring.

The Barrier concept requires DT\&E on surface barrier, leachate collection and monitoring and subsurface barrier installation. Placement of a subsurface barrier under an existing waste pile is a first-of-a kind concept and is unproven. DT\&E needs for ISV include handling metals and large volumes of combustibles, site specific demonstration, and model development (gas transport, fluid flow, heat exchange, process chemistry, etc.) to support process design and safety analysis.

Potential advantages of the Barrier and ISV concepts are that they may have less safety and health impacts and cost less than ex-situ concepts. Also, they provide an interim remediation solution that may be acceptable for 
the long term. Alternate technologies could be developed during this interim period that could provide better long-term solutions. ISV modifies the waste into a near monolithic structure of essentially homogeneous composition. 


\section{CONCEPTS PRODUCING WASTE FORM 2}

Three system concepts were considered for the leach resistant final waste form: Melting/Incineration System with LLW Presort (2-EG-2), ISV and Retrieval Processing System (2-EB-3), and Melting/Incineration System with LLW Postsort (2-EG-4).

In the Melting/Incineration System with LLW Presort, first a Retrieval subsystem is used to exhume the waste. The output from the Retrieval subsystem includes three major waste streams: peripheral soil, metals, and intact drums/loose objects. Peripheral soil and metals waste streams are treated by a Soils Processing and Metals Sizing/Decon subsystems, respectively. The third waste stream, intact drums/loose objects, is processed in the main processing facility. In this facility, the waste is sorted into LLW, combustibles, and noncombustibles. LLW is processed in a LLW Processing subsystem. The noncombustible and combustible streams are processed through a melting furnace and an incinerator, respectively. The incinerator ash is then processed through the melting furnace with the noncombustible waste. Most of the process byproducts including TRU metal and residue output from the Metal Sizing/Decon subsystem, TRU soil from the Soils Processing subsystem, and incinerator ash are fed to the melting furnace. The melter output is a leach-resistant slag.

The ISV and Retrieval Processing subsystem involves ISV followed by removal of the vitrified waste. A special retrieval concept utilizing rock fracturing techniques will be needed for this concept. After retrieval, the fractured rock is placed in containers and prepared for disposal. Fines and loose material generated during the retrieval operations are brought to a processing facility and vitrified using a Joule melter.

The third system concept, Melting/Incineration System with LLW Postsort, is principally the same as the Melting/Incineration System with LLW Presort concept. The only difference is that all of the incoming intact drum/loose objects waste stream is processed through the incinerator/melter trains. In 
this concept, LLW is separated out at the end of the melting/incineration process.

Two types of Melter/Incinerator System concepts were studied primarily to determine the advantages and draw backs of presorting LLW as compareo to postsorting. The advantage of the LLW presorting concept is a potential savings in the disposal costs because the volume of TRU waste requiring disposal is anticipated to be much less than the LLW postsorting case. The disadvantage of the LLW presorting concept is that a separate subsystem encompassing several unit operations will be needed.

The significant advantages for melting and incineration concepts are the waste reduction and conversion of the waste to a benign form. The significant disadvantages are the potential for large volumes of off-gas and the need for secondary burners to further treat the off-gas. The melting and incineration system concepts require significant leadtime for DT\&E of the incineration and melter unit operations. DT\&E will also be needed to determine the type and amount of soil and other additives to convert the incoming waste streams into a high integrity glass waste form.

The ISV and Retrieval Processing concept also achieves volume reduction and produces a final waste form that is high integrity and is benign. In addition, removing the vitrified waste would be safer and much less complicated than removing untreated waste. Disadvantages of the ISV and Retrieval Processing are that some waste materials could present processing problems. For example, large metal objects could cause a short between the electrodes, and compressed gas cylinders and barrels of organic liquids could overwhelm the off-gas treatment system. Major DT\&E needs for this system include movable electrodes, handling metals and large volumes of combustibles, site specific demonstration, modeling (gas transport, fluid flow, heat exchange, and process chemistry), fracture and retrieval dust control, Joule heated melter concept, and investigation of additives to ensure proper melting and product quality. 


\section{CONCEPTS PRODUCING WASTE FORM 3}

For the LDR compliance and restriction on hydrogen generation waste form, five systems were considered: Thermal Treatment/Solidification System with LLW Presort (3-IT-1), Thermal Treatment/Solidification System with LLW Postsort (3-IT-3), Pyrolysis/Acid Leach with Plutonium Extraction System (3-EB-6), Molten Salt Oxidation System (3-BE-7), and Chemical 0xidation/ Solidification System (3-IT-8).

The Thermal Treatment/Solidification System with LLW Presort and Postsort concepts were chosen to determine the effects of separating LLW before or after the main processing of TRU waste. In each case, LLW and TRU waste streams had to meet the LDR requirements, whereas the TRU waste had to also meet the hydrogen generation minimization requirement.

The five system concepts employ Retrieval, Soils Processing, and Metal Sizing/Decon subsystems to exhume the waste and process the peripheral soils and metals waste streams. The remaining waste streams, intact drums/loose material, is processed in a waste processing and packaging facility.

In the Thermal Treatment/Solidification System with LLW Presort, loose material is first assayed and sorted out. LLW is sent to a LLW Processing subsystem where it is treated and packaged in compliance with the LDR requirements. TRU sludges are solidified in one of several solidification agents while combustibles and inerts are processed through a thermal treatment system. The resultant ash from the thermal process is similarly immobilized. The Thermal Treatment/Solidification System with LLW Postsort concept is principally the same as the Presort concept. The only difference is that all of the incoming intact drum/loose objects waste stream is processed through the thermal treatment/solidification process trains. In this concept, LLW is separated out at the end of the melting/incineration process.

The Pyrolysis/Acid Leach with Plutonium Extraction System concept was chosen to determine the effects of separating out plutonium in order to 
minimize the volume of TRU waste and, hence, maximize the volume of LLW. This is accomplished $r$. pyrolizing combustible material to reduce volume and destroy organic contaminants. Plutonium is extracted from the pyrolysis char by acid leaching. Noncombustible waste, solids from the acid leach process, and wastes from the pyrolysis off-gas treatment are solidified to fix inorganic contaminants.

The Molten Salt 0xidation (MSO) System and Chemical Oxidation/ Solidification System concepts were chosen to determine if alternative thermal treatment and biotreatment options may be viable. The MSO concept utilizes a two-stage molten salt oxidizer to thermally reduce and destroy the incoming combustible wastes. The MSO off-gas treatment unit operation examines, quantifies, and treats the process stream to permit release to the environment. MSO secondary waste is treated by a liquid waste treatment unit operation. A solidification unit operation receives fines, liquids, and organic waste by-products, and combines these utilizing physical or chemical processes to solidify the materials.

In the Oxidation/Solidification System concept, combustibles, inerts, and sludges are processed through an oxidation unit operation. The incoming noncombustibles and large inerts are treated to remove organic and oxidizable inorganic constituents using a chemical oxidation process such as super-critical water, wet oxidation, or acid digestion. Residual organic constituents from the oxidation process are treated by biological processes or carbon adsorption. Gases are treated in an off-gas unit operation. Effluents are treated in a liquid waste treatment unit operation to remove radioactive contamination. Residues are sent to the solidification system.

All of the above five system concepts will require DT\&E on solidification media and formulations, and incoming waste characterization techniques. In these concepts, characterization of the incoming waste will be a critical factor because it will be the basis for applying the LDR treatment requirements. 
The Thermal/Solidification concepts will require DT\&E on the thermal destruction unit operation. In the Pyrolysis/Acid Leach with Plutonium Extraction System concept, all of the eight major unit operations in the system utilize state-of-the-art technologies. Each of these unit operations is currently available and individually demonstrated. However, there is a lack of specific performance data on the type of waste materials that will actually be processed through the system. The necessary data can be generated ihrough DT\&E.

In the MSO concept, high aluminum/silicon ash combined with an excessive oxygen level dynamically increases viscosity to the point of solidification, thereby rendering the melt useless. It is anticipated that the MSO process will have difficulty with the SIDA waste streams because of the high soil content.

Approximately one-third of the major unit operations in the Oxidation/Solidification system concept will require DT\&E. These include inerts treatment, chemical oxidation, biotreatment/adsorption, liquid waste treatment, and lead decontamination unit operations. Some additional DT\&E will be required for solidification of sludges. The application of chemical oxidation and biotreatment techniques may complicate the integration of unit operations from the standpoint of system waste throughput. 0xidation and biotreatment are typically slower processes than, for example, incineration. 


\section{CONCEPTS PRODUCING WASTE FORM 4}

For the final waste form meeting WIPP and TRAMPAC requirements, two systems were considered: the Sort, Treat, and Repackage System (4-BE-2) and the Volume Reduction and Repackage System (4-BE-4). The Sort, Treat, and Repackage System was chosen as the conventional system meeting the minimum requirements of WIPP and TRAMPAC. The Volume Reduction and Repackage System was chosen to provide a basis for volume reduction in order to extend the capacity of WIPP.

As with waste forms 2 and 3 , waste form 4 concepts employ the Retrieval, Soils Processing and Metals Sizing/Decon subsystems. The intact drums/loose objects are brought to a waste processing, packaging facility.

In the Sort, Treat, and Repackage System concept, the incoming waste is segregated into five streams. These include combustibles and noncombustibles, organic and inorganic sludge, fines and liquid waste, plastic bags, and compressed gas cylinders. Each of the five waste streams are treated by various unit operations according to the specific WIPP-WAC and TRAMPAC-II waste form compliance requirements. A significant advantage of this system is that the processes employed by the system are all in use and well-known. The technologies require DT\&E only in alpha cell integration areas.

In the Volume Reduction and Repackage System concept, the incoming LLW stream is sorted out and fed to the LLW subsystem. The TRU waste stream is segregated into combustibles and noncombustibles, compressed gas cylinders, inorganic sludge, organic sludge, plastic bags, and liquid waste. Each of the four waste streams is treated by a volume reduction process such as incineration, super-compaction, etc. In addition to volume reduction, these processes treat the output to meet the specific WIPP-WAC and TRAMPAC-II waste form compliance requirements. This system concept also employs proven and well-known concepts. The technologies require DT\&E only in alpha cell integration areas. 


\section{SUBSYSTEM CONCEPTS}

When the same unit operation was employed by a majority of the system concepts, the unit operation was designated as a subsystem and was developed independent of the system concept. Four such subsystems were considered in the SDS: Metals Sizing/Decon subsystem ( $S-B E-1)$, Soils Processing subsystem (S-EB-2), LLW Processing subsystem (S-IT-3), and Retrieval subsystem (S-BE-4). The Retrieval, Soils Processing, and Metals Sizing/Decon subsystem are common among all of the ex situ system concepts. The LLW subsystem is used in system concepts that utilize LLW presorting.

The Metal Decontamination/Sizing subsystem is comprised of metal decontamination, liquid waste treatment, and assay unit operations. The significant advantage of this subsystem is that the processes it employs are all well-known and in use. The significant disadvantage is the generation of additional liquid waste without the benefit of free release of metal. The technologies do not require a significant amount of DT\&E. Integration of unit operations in an alpha cell environment and treatment of the waste byproduct may require application engineering and a limited amount of DT\&E.

The Soils Processing subsystem utilized a thermal desorber unit to heat the soil to approximately $450^{\circ} \mathrm{F}$. At or below this temperature, $m$ st volatile and semi-volatile organic compounds are thermally stripped from the soil. The organic vapors are captured in a treatment system consisting of either granular activated carbon or an afterburner and/or scrubber. The organic-free soil is cooled and conveyed to a soil washing operation, based on a physical treatment process that gravimetrically separates the TRU from the larger volume of soil. The clean soil is returned for disposal at SDA while a small portion of soil contaminated with concentrated TRUs and heavy metais, is dewatered and packaged for further processing by the parent system. The Soil Processing subsystem will require DT\&E in all of the major unit operations including soil washing, removal of TRU from liquid, and the thermal desorption process. 
In the LLW Processing subsystem, LLW sludges are solidified in one of several solidification agents: combustibles and inerts are processed through a thermal treatment system and the resultant ash is similarly immobilized. The system utilizes commercially available techniques except solidification techniques requiring LDR compliance. DT\&E will be required to define suitable solidification processes for the various waste streams.

The Retrieval subsystem characterizes, retrieves, gross sorts, and packages the material for transportation to the waste processing facilities. The subsystem has three major output waste streams: peripheral soils, metals, and intact drums/loose objects. These streams are sent to other subsystems and the main processing system for treatment. The retrieval operation is accomplished inside a mobile alpha environmental enclosure. The enclosure is moved as needed to cover retrieval operations at various pits and trenches. The technologies employed in this subsystem require DT\&E to integrate the unit operations of non-intrusive characterization and remote excavation. Furthermore, application engineering efforts may be needed to develop an optimum alpha enclosure design. 


\section{CONCEPT IMPLEMENTATION RISK ASSESSMENT SUMMARY}

For each of the system concepts, the programmatic risks associated with implementing the concept were assessed to identify major uncertainties requiring focused work and attention, and to provide a degree of confidence that the Program can be executed to meet the technical, safety and health, institutional, schedule, and cost objectives.

Because the Buried Waste Program is still in the initial phase of the data acquisition process, detailed information for a full risk analysis does not yet exist. Hence, the qualitative judgements, based on several assumptions were used (see Volume II). This was done by applying the knowledge of experienced personnel to rank each of the program objectives as low, moderate, or high. A summary of the risk characterization for the various system concepts is presented in Table $1-1$. 
Table 1-1. Program implementation risk summary

\begin{tabular}{|c|c|c|c|c|c|c|}
\hline System Concept & Number & Technical & Health and Safety & Institutional & Schedule & Cost \\
\hline Barrier & $1-B E-1$ & Moderate & Low & High & Moderate & Moderate \\
\hline In situ vitrification & $1-E B-2$ & Moderate & Low & High & Moderate & Moderate \\
\hline $\begin{array}{l}\text { Melting/incineration } \\
\text { system with low-level } \\
\text { waste (LLW) presort }\end{array}$ & $2-E G-1$ & Moderate & Moderate & High & Moderate & Moderate \\
\hline $\begin{array}{l}\text { Melting/incineration } \\
\text { system with LLW postsort }\end{array}$ & $2-E B-3$ & Moderate & Moderate & High & Moderate & Moderate \\
\hline $\begin{array}{l}\text { In situ vitrification } \\
\text { (ISV) and retrieval } \\
\text { processing system }\end{array}$ & 2-EG-4 & Moderate & Moderate & High & Moderate & Moderate \\
\hline $\begin{array}{l}\text { Thermal treatment/ } \\
\text { solidification system } \\
\text { with LLW presort }\end{array}$ & $3-I T-1$ & Moderate & Low & High & Low & Moderate \\
\hline $\begin{array}{l}\text { Thermal treatment/ } \\
\text { solidification system } \\
\text { with LLW postsort }\end{array}$ & $3-1 T-3$ & Moderate & Low & High & Low & Moderate \\
\hline $\begin{array}{l}\text { Pyrolysis/acid leach } \\
\text { with plutonium } \\
\text { extraction system }\end{array}$ & $3-E B-6$ & High & Moderate & High & Moderate & High \\
\hline $\begin{array}{l}\text { Molten salt oxidation } \\
\text { system }\end{array}$ & $3-8 E-7$ & High & Moderate & High & Moderate & Moderate \\
\hline $\begin{array}{l}\text { Chemical oxidation/ } \\
\text { solidification system }\end{array}$ & $3-I T-8$ & High & Moderate & Low & Moderate & High \\
\hline $\begin{array}{l}\text { Sort, treat, and } \\
\text { repackage system }\end{array}$ & $4-B E-2$ & Moderate & Low & Low & Low & Moderate \\
\hline $\begin{array}{l}\text { Volume reduction and } \\
\text { repackage system }\end{array}$ & $4-B E-4$ & Moderate & Moderate & Low & Low & Moderate \\
\hline
\end{tabular}




\section{SUMMARY OF ROUGH ORDER OF MAGNITUDE (ROM) COST ESTIMATES}

Rough Order of Magnitude (ROM) cost estimates for the 12 systems and 4 subsystems were developed by the SDS team and reviewed by an independent team to facilitate an accurate cost comparison between the system concepts. ROM life cycle cost estimates including cost per cubic yard are summarized in Figure I-1. The ROM cost estimates include DT\&E, facility construction costs, and annual operational costs. Costs that were not included are the offsite utility cost of power, water, and sewer and laboratory facilities. For ex situ options, disposal costs for the waste has not been included and is very important from a total 1 ife-cycle-cost perspective.

A key conclusion of the cost assessment effort is that the overall system concept cost is dominated by size of the facility alpha cells required for waste processing. Hence, a more detailed design study is needed to optimize the facility layout and to adequately define the alpha cell space requirements. It is believed that the ROM cost estimates in SDS should be further developed before they are used for budgetary planning or as a tool for decision making. 


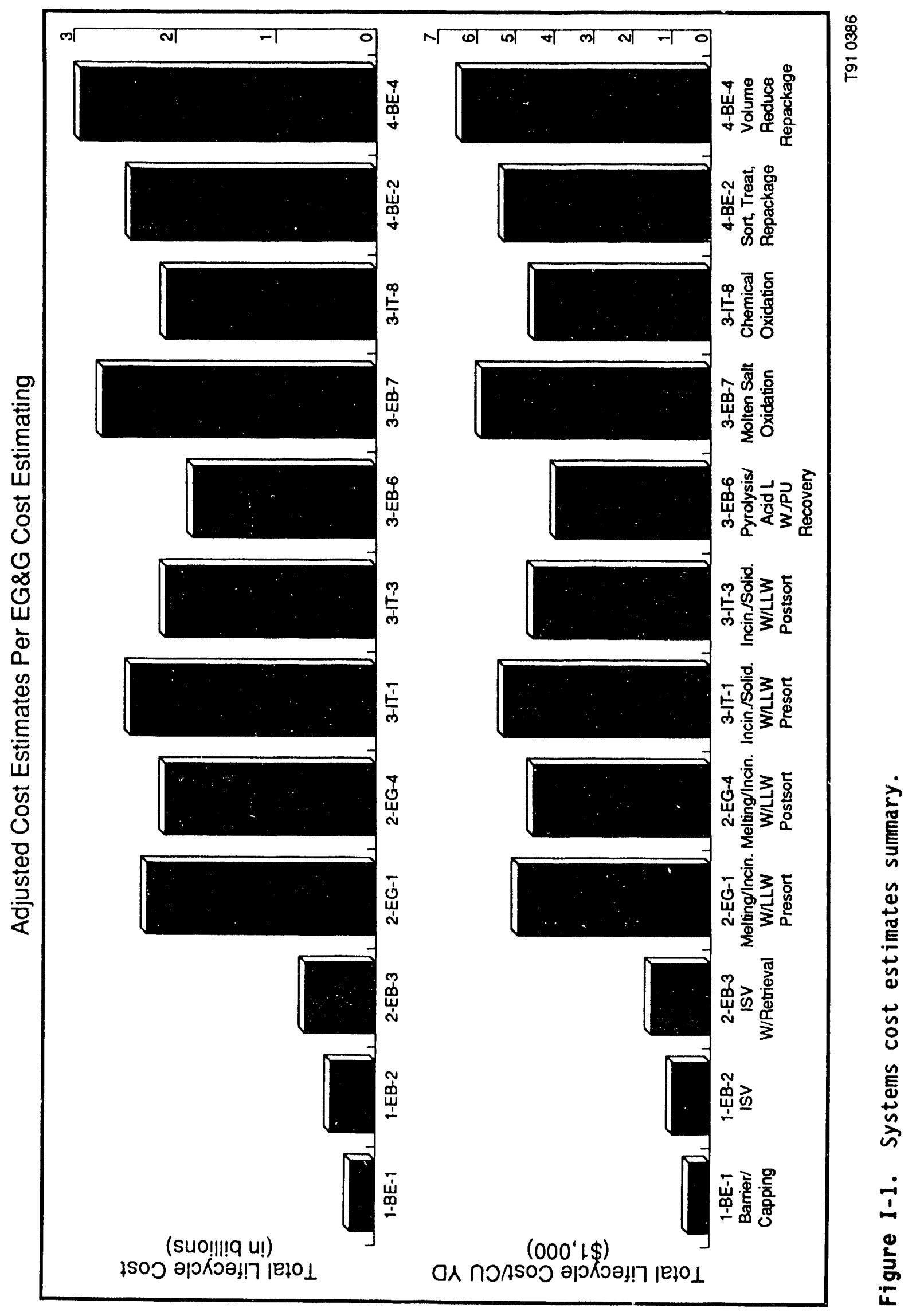




\section{RDDT\&E SUMMARY SCHEDULE}

Summary DT\&E schedules of all systems and subsystems are presented in Figure I-2. Further evaluation of these schedules are required before conclusions can be drawn as to which final waste form or system will take longer to develop before design and construction can take place. 


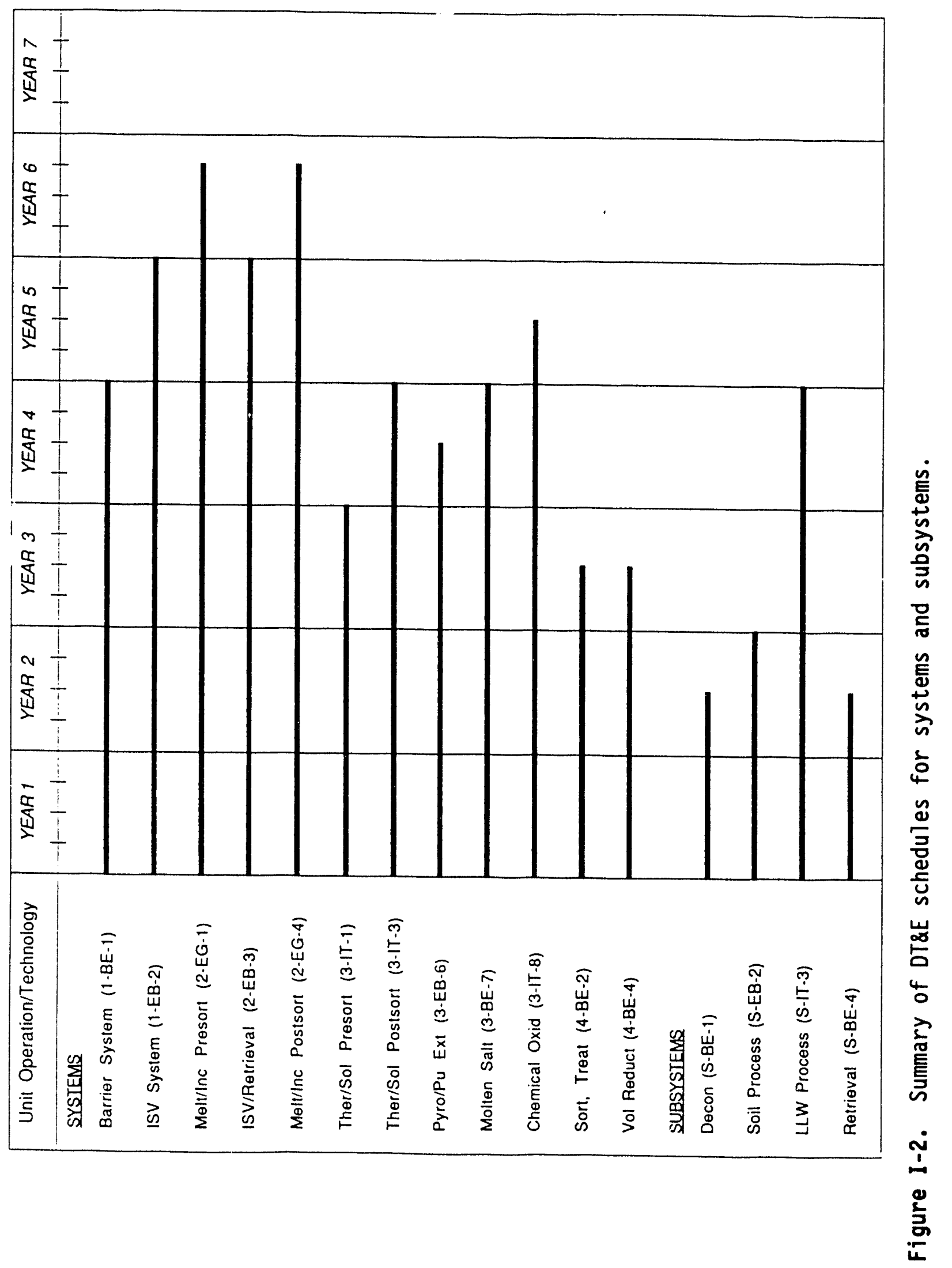




\section{RECOMMENDATIONS}

Based on the SDS results, the following recommendations are made on technology requirement development strategy, system concepts ranking strategy, viable concepts and major unit operations employed in the concepts, and future activities for the systems engineering task.

\subsection{Technical Requirements Development Strategy}

A primary recommendation of the SDS is that the selected system concepts should allow for flexibility in decision making. Figure I-3 shows the major decision points and concepts considered in the SDS to facilitate the decision making. At this point in the Buried Waste Program, it is imperative that work on viable system concepts, covering both in situ and ex situ treatment options, continue in parallel.

\subsection{System Concepts Ranking Strategy}

Ranking of the 12 concepts can be done against several different attributes. Furthermore, a different weighing factor distribution for each attribute can be argued depending on the political issues versus technical performance. For the SDS, a combination of the following three ranking cases is suggested.

\begin{tabular}{|c|c|c|c|}
\hline Program Implementation Risk Category & Case 1 & Case 2 & Case 3 \\
\hline Performance objectives compliance & $50 \% \times S 1$ & $20 \% \times S 1$ & $100 \% \times S 2$ \\
\hline Health and safety objectives compliance & $20 \% \times S 1$ & $15 \% \times S 1$ & $0 \%$ \\
\hline Institutional objectives compliance & $15 \% \times S 1$ & $50 \% \times S 1$ & $0 \%$ \\
\hline Schedule objectives compliance & $10 \% \times \mathrm{Sl}$ & $10 \% \times S 1$ & $0 \%$ \\
\hline Cost objectives compliance & $5 \% \times S 1$ & $5 \% \times S 1$ & $0 \%$ \\
\hline
\end{tabular}




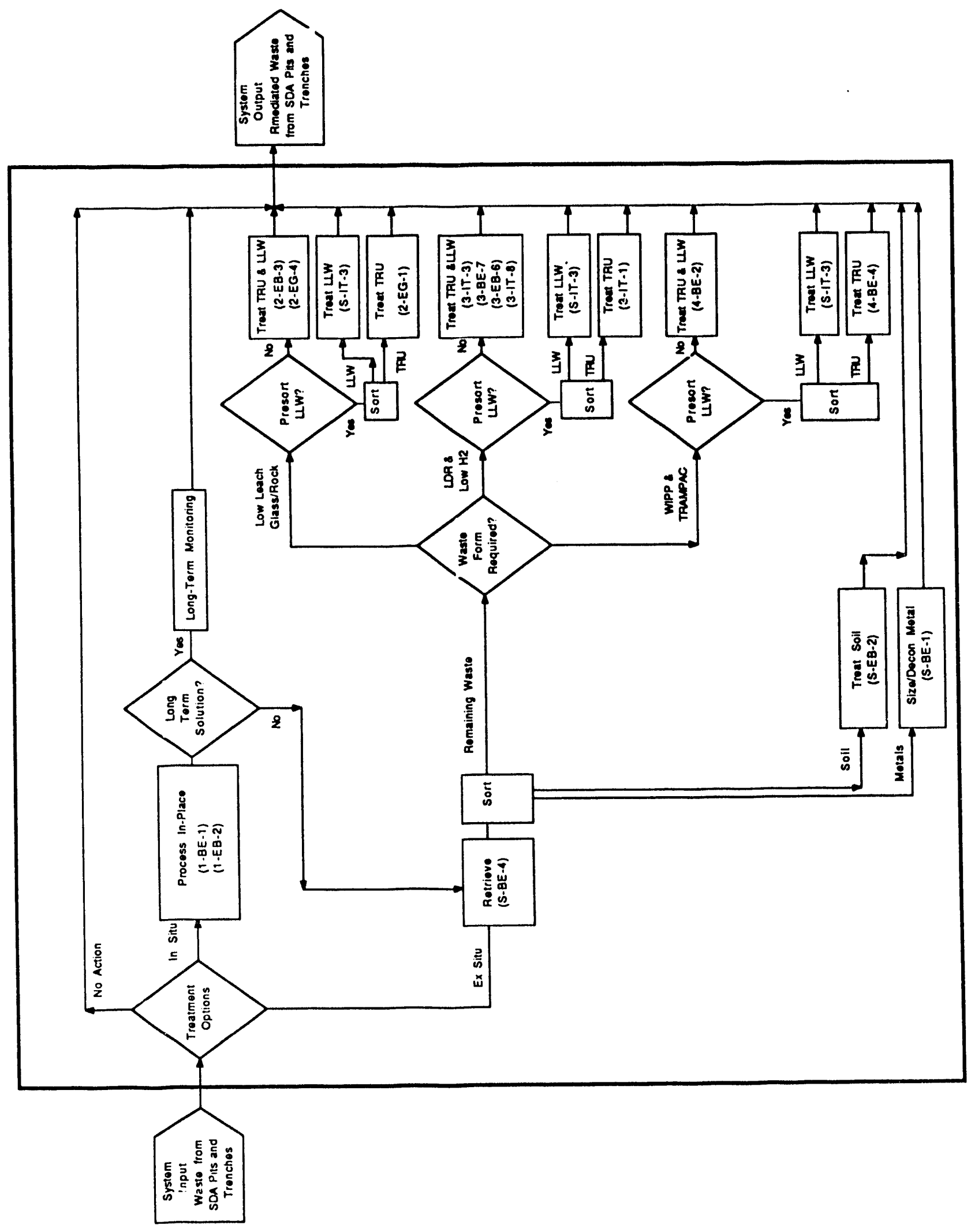

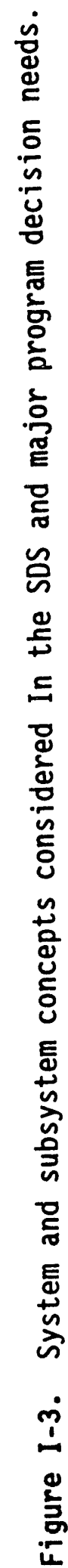


S1 = Score based on concept implementation risk characterization (High Risk $=1$, Moderate Risk $=2$ and Low Risk $=3$ ).

S2 $=$ Score based on waste form (Waste From $2=3$, Waste Form $3=2$ and Waste Form $4=1$ ).

Cases 1 and 2 are based on the qualitative risk characterizations related to the concept implementation. The recommended distribution of the weighing factors in Case 1 is based on giving the highest emphasis to technical performance objectives compliance. In Case 2, compliance with institutional objectives are given the highest emphasis. A third ranking case, based on the quality of waste form produced by the ex situ concepts, is employed. In Case 3, waste form 1 concepts should not be addressed because their waste form is not comparable with the ex situ concepts.

A summary of such ranking is presented in Table $\mathrm{I}-2$. In Cases 1 and 2, systems having an accumulative score in the top 25 percent are given a high ranking, systems in the middle 50 percent are ranked as moderate, and those in the bottom 25 percent are given a low ranking. In Case 3, system concepts receiving a score of 3 (Waste Form 2) are given high ranking, those receiving a score of 2 (Waste Form 3) are given moderate ranking, and systems concepts receiving a score of 1 (Waste Form 4) are given low ranking.

\subsection{Acceptable Concepts}

For ex situ treatment concepts, the melting/incineration system concepts produce a superior waste form that could be acceptable for the LDR compliance and WIPP disposal scenarios. However, a major disadvantage of this strategy 
Table I-2. System concepts ranking

\section{System Concept}

Barrier

In situ vitrification

Melting/incineration with LLW presort

ISV and retrieval processing

Melting/incineration with LLW postsort

Thermal treatment/solidification with LLW presort

Thermal treatment/solidification with LLW postsort

Pyrolysis/acid leach with plutonium extraction

Molten salt oxidation

Chemical oxidation/solidification

Sort, treat, and repackage

Volume reduction and repackage system
Number Case 1 Case 2 Case 3

$1-B E-1 \quad M$

1-EB-2 M

2-EG-1 $\quad M$

2-EB-3 $\quad M$

2-EG-4 H

3-IT-1 M

3-IT-3

M

M

$3-E B-6$

L

L

3-BE-7

L

L

3-IT-8 L $\quad H \quad M$

4-BE-2 H H

4-BE-4 H
H

M
M

M

M

H

H

H

M

L

L 
The presorting of LLW has a seemingly economic advantage because once it is segregated, LLW can be treated in a low-cost facility with a lower hazard classification than a TRU waste treatment facility. The disadvantage of presorting LLW is that it increases the number of waste handling and treatment unit operations and will require development of a reliable assay technique. In the SDS, the complicated LLW presorting issues were not addressed in enough detail to justify a decision on an LLW treatment strategy. As a result, it is suggested that development of a LLW subsystem continue into the next phases of the concept exploration until additional data to support a decision is developed.

In summary, the following is recommended:

- Continue concept exploration of the two in situ concepts (1-BE-1 and $1-E B-2)$.

- Continue concept exploration of the three waste ex situ concepts (2-EG-1, 2-EB-3, and 2-EG-4) producing waste form 2.

- Continue concept exploration of the four subsystems (S-BE-1, S-EB-2, S-IT-3, and S-BE-4).

In addition, the following is also recommended:

- Among systems producing waste form 3, the two Thermal Treatment/ Solidification system concepts (3-IT-1 and 3-IT-3) are not recommended because they use thermal processes that duplicate the processes contained in the Incinerator/Melter concepts. The Molten Salt Oxidation and the Pyrolysis, and Acid Leach with Pu Extraction concepts (3-EB-6 and 3-BE-7) are not recommended because they received low ranking. The remaining concept, the Chemical/0xidation/Solidification (3-IT-8) system, uses non-thermal processes. Therefore, it is recommended that this concept be further explored. The concept should use feasible nonthermal treatment techniques. 
- The two options producing waste form 4 (4-BE-2 and 4-BE-4) use unit operations that are basically similar to the melter/incinerator or thermal treatment/solidification concepts recommended above. As a result, it is recommended that system concepts producing waste form 4 be dropped from further consideration. These concepts can easily be revived in the future, if needed.

\subsection{Recommendations for Future Activities}

DT\&E Activities: Detailed recommendations on DT\&E are presented in Volume II of the SDS report. A summary is presented in Table I-3. Preliminary ROM estimates and lead time scheciules are presented for the DT\&E activities. Before they can be used, this data requires more detailed development, specifically by those organizations performing these DT\&E activities. Hence, it is recommerided that before any planning of DT\&E activities, a detailed assessment of the cost and schedules should be prepared.

Systems Engineering Tasks: The next phase of the systems engineering should proceed first by developing a systems requirements document. This document should be based on the results of this study and should contain input/output requirements, performance requirements, technology requirements, utilization of resource $(U / R)$ requirements, tradeoff $(T / 0)$ requirements, and system test requirement. Some of the activities needed to accomplish the above tasks are development of incoming waste characteristics, further exploration of concepts, cost estimation, and development of figure of meri: analysis criteria. 
Table I-3. DT\&E summary

System/Subsystem Concept

Process in place/leave in place concepts

High integrity waste form concepts

LDR compliance and $\mathrm{H}_{2}$ generation reduction concepts
DT\&E Areas

- Techniques for placement of barriers and leachate collection below the waste piles.

- Surface barriers longevity, intrusion protection

- Methods to accurately detect the depth of the vitrified melt in ISV

- Determine the fate of volatile organics during ISV

- ISV off-gas collection and treatment system

- Improve on ISV waste form homogeneity and leach resistant encapsulation,

- Investigate cooling rates of large ISV sites

- Investigate excavation techniques for ISV waste retrieval

- Perform DT\&E needed to select melter process

- Investigate plasma pyrolysis, plasma arc furnace, plasma centrifugal reactor Joule melter, gas cyclonic, and slagging pyrolysis melter techniques

- Perform DT\&E needed to select an incineration process

- Investigate applicability of rotary kiln, controlled air, fluidized bed, infrared and pyrolysis techniques

- Throughput and applicability of supercritical water, wet oxidation, or acid digestion

- Applicability of biological treatment or carbon adsorption processes 
Table I-3. (continued)

System/Subsystem Concept

DT\&E Areas

- Characterization of the incoming waste in order to allow for determination of the applicable LDR treatment requirements

- Solidification and treatment techniques for the sludges, volume reduction of combustibles, solidification of the various treated waste products, and decontamination, treatment, and stabilization of lead

Metal sizing and decontamination subsystem

Soils treatment

LLW processing subsystem

Retrieval subsystem

- Effectiveness of decontamination methods in alpha cell environment

- Decontamination liquid/sludge waste treatment

- Thermal desorption of organic materials from soils

- Removal/reduction of Pu from large quantities of soils

- Removal/reduction of TRU in liquids

- LDR treatment of sludges, lead, and combustibles

- LDR stabilization treated waste products

- Investigation of techniques to eliminate hazardous constituents in metals and inerts

- Characterization of waste and large object identification by non-intrusive technique

- Application of robotics for digging, retrieval and sorting

- Scaling-up of automation and firmware control architecture in full-duplex or closed-loop control schemes

- Integration of passive and active sensor package output to more user friendly data display

- Graphical information system development of the meaningful display of sensor data 
Table I-3. (continued)

System/Subsystem Concept

Assay and sorting
DT\&E Areas

- Sorting of large quantities of waste

- On-line assay and organic volatile detection 

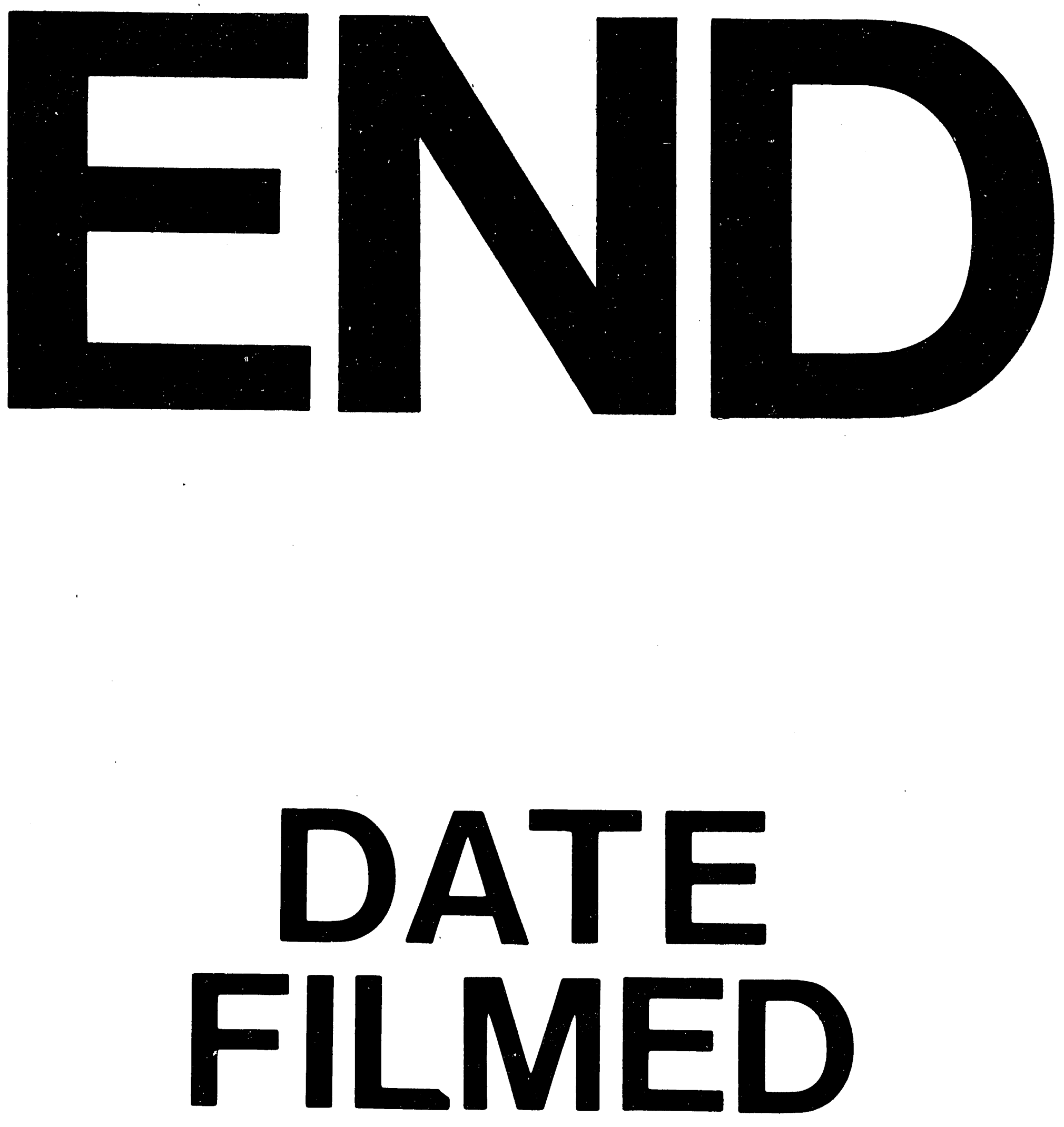

$p$

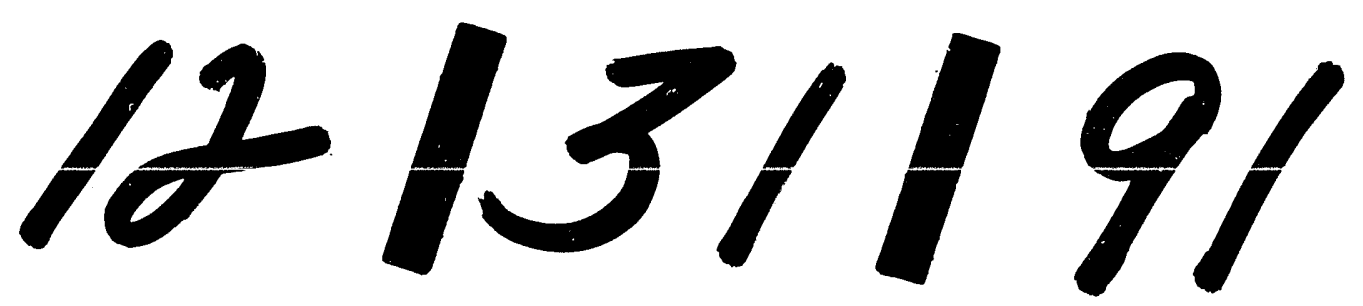

7 
